\title{
MENINGKATKAN HASIL BELAJAR IPA KELAS V SDN - 2 KASONGAN BARU DENGAN METODE DEMONSTRASI BERBANTUAN DENGAN MODEL MIND MAPPING TAHUN PELAJARAN 2017/2018
}

\section{Oleh : Devi Ratna Sari* Dr. Ramli, M.Pd}

\begin{abstract}
ABSTRAK
Penelitian ini bertujuan untuk : (1) mendeskripsikan aktivitas belajar IPA peserta didik kelas V SDN - 2 Kasongan Baru dengan menggunakan metode Demonstrasi berbantuan dengan model Mind Mapping . (2) meningkatkan hasil belajar IPA peserta didik kelas V SDN - 2 Kasongan Baru Kecamatan Katingan Hilir Kabupaten Katingan dengan menggunakan metode Demonstrasi berbantuan dengan model Mind Mapping.

Jenis penelitian yang digunakan adalah Penelitian Tindakan Kelas. Subjek dalam penelitian ini adalah seluruh peserta didik kelas V SDN - 2 Kasongan Baru yang berjumlah 12 orang peserta didik yang terdiri dari 7 orang peserta didik laki-laki dan 5 orang peserta didik perempuan. Teknik pengumpulan data menggunakan tes dan observasi, analisis data secara kualitatif dan kuantitatif.

Hasil penelitian menunjukan bahwa : (1) aktivitas belajar peserta didik dengan penerapan metode Demonstrasi berbantuan dengan model Mind Mapping menjadi baik.Hal ini sesuai dengan keaktifan dan semangat peserta didik dalam mengikuti proses pembelajaran dan dibuktikan dengan hasil observasi pada siklus I aktivitas peserta didik memperoleh skor 3,8 yang termasuk kedalam kategori baik. (2) ada peningkatan hasil belajar IPA pada peserta didik kelas V SDN- 2 Kasongan Baru dengan penerapan metode Demonstrasi berbantuan dengan model Mind Mapping. Dibuktikan dari data pra tindakan atau pre test nilai rata-rata yang diperoleh peserta didik adalah 40 dengan ketuntasan belajar klasikal 16\% sedangkan pada siklus I (post test)memperoleh nilai rata-rata 92 dan nilai ketuntasan klasikal mencapai $100 \%$.
\end{abstract}

\section{Kata Kunci : Hasil Belajar, IPA, Metode Demonstrasi, Model Mind Mapping PENDAHULUAN}

Hasil belajar merupakan hasil yang dicapai peserta didik ketika mengikuti dan mengerjakan tugas dan kegiatan pembelajaran disekolah yang dibuktikan atau ditunjukkan melalui nilai atau angka dari hasil evaluasi yang dilakukan oleh guru terhadap tugas peserta didik dan ulangan-ulangan atau ujian yang ditempuhnya (Tu'u, 2004:75).

Pembelajaran IPA bukan sekedar penguasaan konsep, prinsip, hukum atau teori semata melainkan suatu proses 
dengan cara mengembangkan keterampilan proses dan sikap ilmiah untuk mendapatkan konsep-konsep ilmiah tentang alam semesta. IPA itu sendiri yang dapat dipandang sebagai proses, produk dan pengembangan sikap. Dimensi proses IPA menuntut guru untuk melibatkan peserta didik secara aktif dalam kegiatan-kegiatan dasar yang biasa dilakukan oleh para ilmuwan dalam upaya memperoleh pengetahuan, kegiatan dasar ini sering disebut sebagai metode ilmiah dari keterampilan proses, melalui proses IPA akan ditemukan produk IPA berupa fakta, konsep, hukum dan teori yang diaplikasikan ke dalam teknologi. Keterampilan IPA itu sendiri sangat penting bagi setiap peserta didik sebagai bekal untuk menggunakan metode ilmiah dalam mengembangkan sains serta diharapkan memperoleh pengetahuan baru atau mengembangkan pengetahuan yang telah dimiliki. Dalam kemampuan peserta didik untuk menerapkan metode ilmiah dalam memahami, mengembangkan dan menemukan ilmu pengetahuan. Berdasarkan hasil observasi yang dilaksanaan pada 16 Oktober 2017 tentang pembelajaran IPA di SDN-2 Kasongan Baru Kabupaten Katingan fenomena yang ditemukan pada saat berlangsungnya proses pembelajaran IPA dikelas interaksi aktif positif antara peserta didik dengan guru, atau peserta didik dengan peserta didik jarang terjadi. Peserta didik kurang terampil menjawab pertanyaan atau bertanya tentang materi yang diajarkan mereka cenderung belajar sendirisendiri bahkan banyak di antara mereka yang melakukan aktivitas lain di luar proses pembelajaran. Berdasarkan data yang di dapatkan dari hasil observasi dan wawancara dengan guru kelas $\mathrm{V}$ SDN 2 Kasongan Baru terhadap mata pelajaran IPA bahwa dari jumlah 12 peserta didik yang memperoleh nilai 2060 sekitar 10 orang sedangkan yang memperoleh diatas standar ketuntasan berjumlah 2 orang yang mencapai KKM.

Salah satu solusi yang dapat digunakan untuk mengatasi masalah yang dihadapi adalah dengan mengembangkan metode dan model pembelajaran yang dapat menciptakan suasana belajar yang aktif, menyenangkan, membantu peserta didik memahami materi pelajaran yang sulit, dan membantu guru mengajarkan materi yang kompleks, adalah metode dan model pembelajaran Demonstrasi dan Mind Mapping. Penerapan metode Demonstrasi dimulai dari mempersiapkan peralatan dan bahan yang diperoleh untuk demonstrasi, memberikan pengantar demontrasi untuk mempersiapkan peserta didik mengikuti demonstrasi yang berisikan pelajaran tentang prosedur dan instruksi keamanan memperagakan tindakan, proses, atau prosedur yang disertai penjelasan tentang prosedur, ilustrasi, dan pertanyaan. Sedangkan penerapan model Mind Mapping yang pertama kali dilakukan oleh guru yaitu menyampaikan tujuan pembelajaran yang ingin dicapai, guru menyajikan 
materi, peserta didik dibagi kedalam beberapa kelompok yang anggotanya 2 orang, peserta didik merancang peta

Penelitian ini dilaksanakan dengan menggunakan metode Penelitian Tindakan Kelas (classroom action research). Penelitian tindakan kelas berasal dari bahasa inggris Classroom Action Research, yang berarti penelitian yang dilakukan pada sebuah kelas untuk mengetahui akibat yang dilakukan pada sebuah kelas untuk mengetahui akibat yang diterapkan pada suatu subjek penelitian dikelas tersebut (Kardiawarman, 2007:2). Penelitian Tindakan Kelas didefenisikan sebagai suatu bentuk penelitian yang bersifat refleksi dengan melakukan tindakantindakan tertentu untuk memperbaiki dan meningkatkan praktik pemebelajaran dikelas agar lebih berkualitas sehingga peserta didik dapat memperoleh hasil belajar yang lebih baik.

Adapun menurut Kunandar (2011:42) "Penelitian Tindakan Kelas merupakan bagian dari penelitian tindakan (action research), dan penelitian tindakan ini bagian dari penelitian pada umumnya". Sedangkan menurut Arikunto (2012:58) "Penelitian Tindakan Kelas adalah penelitian tindakan (action research) yang dilakukan dengan tujuan memperbaiki mutu praktik pembelajaran di kelasnya". Penelitian Tindakan Kelas ini berfokus pada upaya untuk pikiran, peserta didik mempresentasekan hasil diskusi secara berkelompok, dan terakhir kesimpulan.

\section{METODE PENELITIAN}

mengubah kondisi sekarang ke arah kondisi yang diharapkan.

Dapat disimpulkan bahwa penelitian tindakan kelas adalah proses mengevaluasi kegiatan proses belajar mengajar yang dilaksanakan secara sistematik dan menggunakan teknikteknik yang relevan. Dari percobaan yang digunakan secara sistematik dan menggunakan teknik-teknik yang relevan maka dapat suatu gagasan perbaikan dalam praktek pembelajaran dikelas. Selain itu, Penelitian Tindakan Kelas juga penelitian yang refleksi yang dilaksanakan secara siklis (berdaur) dimulai dari tahapan perencanaan, tindakan, pengamatan, dan refleksi untuk memecahkan masalah dan mencobakan hal-hal baru demi peningkatan kualitas pembelajaran. Adapun kegunaan penelitian tindakan kelas adalah untuk memecahkan masalah yang teridentifikasikan, meningkatkan tingkat efektivitas dalam proses pembelajaran, prinsip kemitraan dan meningkatkan profesionalitas guru.

Dalam hal ini peneliti menggunakan metode demonstrasi dan model mind mapping sebagai strategi yang digunakan untuk pembelajaran IPA di kelas V SDN-2 Kasongan Baru adapun yang di teliti adalah hasil belajar peserta didik. 
Penelitian ini merupakan Penelitian Tindakan Kelas (PTK) maka dalam pelaksanaannya menuntut kehadiran peneliti dilapangan sebagai tolak ukur keberhasilan untuk memahami kasus yang teliti. Dalam PTK ini peneliti bekerjasama dengan guru bidang studi dilapangan sangat dibutuhkan. Maka kehadiran dan peran peneliti dalam penelitian ini adalah melakukan penelitian dengan dibantu teman sejawat dan guru mata pelajaran IPA yang bertindak sebagai kolabolator atau observer agar penelitian dapat berjalan dengan lancar dan mencapai tujuan pembelajaran yang diinginkan.

Pada penelitian tindakan kelas ini, dilaksanakan di SDN-2 Kasongan Baru pada mata pelajaran IPA. Subjek penelitian ini yaitu seluruh peserta didik kelas V SDN-2 Kasongan Baru Tahun Pelajaran 2017/2018 yang berjumlah 12 orang 7 orang laki-laki dan 5 perempuan.

Dalam mendapatkan data tersebut diperlukan teknik-teknik untuk mencapai suatu tujuan penelitian, salah satunya ialah teknik analisis data. Data yang diperoleh melalui instrument yang telah dikumpulkan sebelumnya diolah menjadi dua jenis data yaitu kualitatif dan kuantitatif. Teknik analisis data yang digunakan dalam penelitian ini menggunakan data kualitatif dan kuantitatif. Mixed Methods Research HASIL DAN PEMBAHASAN

Data dari hasil penelitian ini berupa : 1) pengamatan aktivitas guru atau penelitian campuran merupakan penelitian gabungan dari penelitian kualitatif dan kuantitatif. Menurut Jhon Creswell (2012), "Mixed methods research is an approach to inquiry that combines or associated both qualitative quantitativ form of research." Hal tersebut menunjukan bahwa Mixed Methods atau metode campuran merupakan pendekatan penelitian yang menggambarkan metode penelitian kualitatif dan metode penelitian kuantitatif.

Data kualitatif diperoleh dari hasil observasi yang dimaksudkan untuk mengetahui kelebihan dan kekurangan pembelajaran yang dilakukan. Data kualitatif diperoleh dari aktifitas terhadap guru peneliti dan aktifitas terhadap peserta didik selama proses pembelajaran dengan menganalisis aspek-aspek yang dilihat dalam proses pembelajaran dengan menggunakan metode demonstrasi dan model mind mapping. Data kualitatif berupa lembarlembar observasi hasil belajar dari hasil belajar kepada guru dan peserta didik.

Data kuantitatif diperoleh dari hasil tes yang diberikan pada setiap akhir siklus kegiatan. Hal ini dilakukan untuk mengetahui peningkatan hasil belajar peserta didik dengan menggunakan metode demonstrasi dan model mind mapping. 
dan peserta didik 2) hasil belajar ipa dengan metode demonstrasi berbantuan dengan model mind mapping.

1) Pengamatan aktivitas guru dan peserta didik, Aktivitas guru dan peserta didik dapat dilihat pada tabel dan gambar berikut :

Tabel 1

Aktivitas Guru dan Peserta Didik

\begin{tabular}{|l|l|l|}
\hline No & Aktivitas & $\begin{array}{l}\text { Nilai Rata- } \\
\text { rata }\end{array}$ \\
\hline 1. & Aktivitas Guru & $\mathbf{3 , 7}$ \\
\hline 2. & $\begin{array}{l}\text { Aktivitas } \\
\text { Peserta Didik }\end{array}$ & $\mathbf{3 , 8}$ \\
\hline
\end{tabular}

Grafik Aktivitas Guru dan Peserta Didik

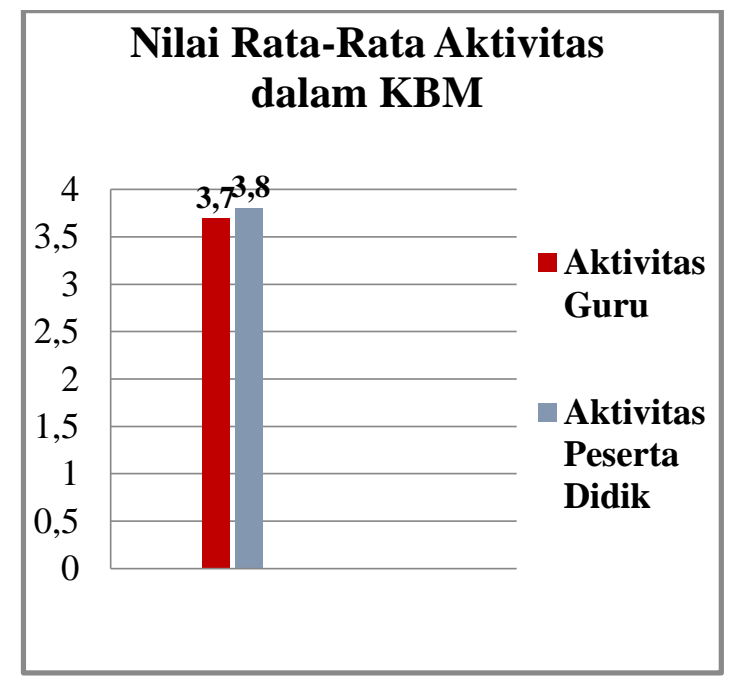

Berdasarkan tabel dan grafik diatas, terlihat jelas bahwa pada nilai rata-rata aktivitas belajar, berdasarkan SIMPULAN

1. Aktivitas belajar peserta didik tanpa ada tindakan dan pra tindakan dapat dikatakan rendah, hal tersebut terbukti dari hasil observasi dan hasil pengamatan yang dilakukan oleh pengamat I dan pengamat II pada siklus I skor rata-rata diperoleh untuk pengamatan aktivitas guru adalah 3,7 yang termasuk dalam kategori baik. Sedangkan pada aktivitas peserta didik dalam pelaksanaan siklus I memperoleh skor rata-rata 3,8 yang termasuk dalam kategori baik.

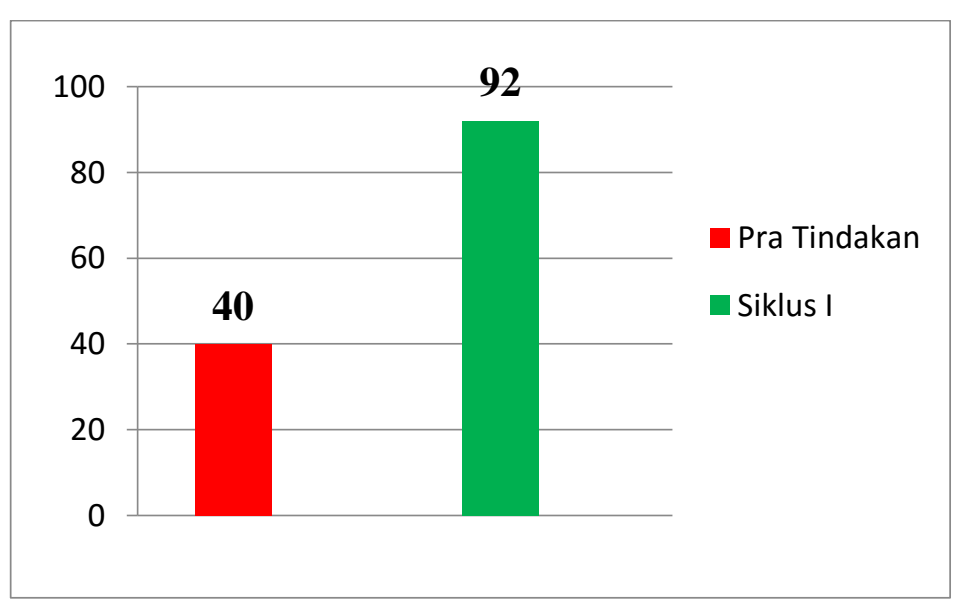

Berdasarkan grafik diatas, terlihat jelas bahwa pada nilai rata-rata hasil belajar pada pre test dan post test mengalami peningkatan. Dengan demikian, dapat dibuktikan bahwa dengan menerapkan metode Demonstrasi berbantuan dengan model Mind Mapping dapat meningkatkan hasil belajar peserta didik kelas $\mathrm{V}$ SDN- 2 Kasongan Baru sehingga penelitian tindakan kelas ini dapat dianggap berhasil.

wawancara dengan guru kelas $\mathrm{V}$ bahwa dari jumlah 12 peserta didik yang memperoleh nilai 20-60 sekitar 10 orang sedangkan yang memperoleh diatas standar 
ketuntasan berjumlah 2 orang yang mencapai KKM. Sedangkan pada saat tindakan aktivitas belajar peserta didik dengan penerapan metode Demonstrasi berbantuan dengan model Mind Mapping menjadi baik. Hal tersebut terlihat dari keaktifan dan semangat peserta didik dalam mengikuti proses pembelajaran dan dibuktikan dengan hasil observasi pada siklus I aktivitas peserta didik memperoleh skor 3,8 yang termasuk kedalam kategori baik.

2. Ada peningkatan hasil belajar IPA pada peserta didik kelas V SDN- 2 Kasongan Baru dengan penerapan metode Demonstrasi berbantuan dengan model Mind Mapping.

\section{DAFTAR PUSTAKA}

Arikunto, S., (2012), Penelitian Tindakan Kelas, Jakarta : Bumi Aksara.

Creswell, John.W. (2012). Research Design, Qualitative, Quantitatrive, and Mixed Methods Approaches, International Student Edition. Los Angeles : SAGE.

Widiasarana Indonesia.
Dibuktikan dari Berdasarkan data yang di dapatkan dari hasil observasi dan wawancara dengan guru kelas $\mathrm{V}$ SDN 2 Kasongan Baru terhadap mata pelajaran IPA bahwa dari jumlah 12 peserta didik yang memperoleh nilai 20-60 sekitar 10 orang sedangkan yang memperoleh diatas standar ketuntasan berjumlah 2 orang yang mencapai KKM. Dibuktikan dari data pra tindakan atau pre test nilai rata-rata yang diperoleh peserta didik adalah 40 dengan ketuntasan belajar klasikal $16 \%$ sedangkan pada siklus I (post test)memperoleh nilai rata-rata 92 dan nilai ketuntasan klasikal mencapai $100 \%$.

Kardiawarman. (2007). Penelitian Tindakan Kelas. Jakarta : Direktorat Pembinaan Pendidikan dan Penelitian.

Kunandar, (2011), Penelitian Tindakan Kelas, Jakarta : Rajawali Pers.

Tu'u, (2014), Peran Displin Pada Perilaku dan Prestasi Peserta Didik, Jakarta : PT. Gramedia 
Tunas Jurnal Pendidikan Guru Sekolah Dasar, Juni 2019, Volume 1 Nomor 2, (1-8)

ISSN : 2477-6076 